\title{
Viselkedésértés - A magatartástudomány eredményeinek hasznosítása a szakpolitika alkotásban
}

\author{
Behaviour insights - Applying the results of behaviour sciences to policy \\ making
}

\author{
Szerzők: Taller Ágnes $\bowtie$, Csizmadia Péter
}

Nemzeti Egészségfejlesztési Intézet

Beküldve: 2016.06.21.

\begin{abstract}
Összefoglaló: Az elmúlt években a viselkedésértés elmélete fokozatosan elismerésre került a nagy nemzetközi szervezetek (Európai Bizottság, OECD, Világbank) által, mint a szakpolitika kialakításának hatékony eszköze. 2010-ben az Egyesült Királyság kormánya alapított viselkedésértéssel foglalkozó tanácsadó testületet (Behaviour Insights Team), 2015 óta pedig az Amerikai Egyesült Államokban kormányrendelet írja elő, hogy a kormányszerveknek be kell építeniük szakpolitikáikba a Társadalom- és Viselkedéstudományi Csoport (Social and Behavioral Sciences Team) felismeréseit. Különböző intézményesített formában Hollandia, Németország, Franciaország és Dánia is foglalkozik a témával. A közlemény a viselkedésértés elméleti alapjainak áttekintését követően az egészségfejlesztésben való alkalmazás néhány gyakorlati példáját ismerteti. Összességében elmondható, hogy a viselkedésértés alkalmazása hatékonyabbá teheti az intézkedéseket az egészségfejlesztés terén is, azonban egyelőre számos kérdést felvet a legitimáció, a hatásosság és a tudományos megalapozottság tekintetében. A viselkedésértés átlátható és következetes alkalmazása érdekében a jövőben javasolt az adott beavatkozások hatásosságának vizsgálata, és az ezzel kapcsolatos tapasztalatcsere.
\end{abstract}

Kulcsszavak: viselkedésértés, magatartástudomány, egészségfejlesztés

Summary: Behaviour insights are increasingly being recognised in the last years by major international bodies (European Commission, OECD, World Bank) as an efficient tool in policy making. In the United Kingdom, an advisory body was set up by the government in 2010 to study behaviour insights (Behaviour Insights Team) and from 2015, an Executive Order calls for Federal Agencies in the United States of America to design government policies using findings of the Social and Behavioral Sciences Team. The Netherlands, Germany, France and Denmark also address this issue in different institutional structures. This paper reviews the theory of behaviour insights and describes some of its practices in health promotion. To sum it up, applying behaviour insights can improve the efficiency of health promotion measures, as well, however, at the moment there are a number of issues to consider in relation to its legitimacy, effectiveness and scientific foundations. In order to apply behaviour insights in a transparent and consistent way, future evaluation of the interventions' effectiveness as well as exchanging experiences are advised.

Keywords: behaviour insights, behaviour sciences, health promotion 
MIT JELENT TULAJDONKÉPPEN A VISELKEDÉSÉRTÉS, VALAMINT MILYEN ELMÉLETI ALAPJAI VANNAK?

Az elmúlt években a viselkedésértés elmélete fokozatosan elismerésre került a nagy nemzetközi szervezetek (Európai Bizottság, OECDi, Világbank) által, mint a szakpolitika kialakításának hatékony eszköze. 2010-ben az Egyesült Királyság kormánya alapított viselkedésértéssel foglalkozó tanácsadó testületet (Behaviour Insights Team - a továbbiakban: BIT), 2015 óta pedig az Amerikai Egyesült Államokban kormányrendelet írja elő, hogy a kormányszerveknek be kell építeniük szakpolitikáikba a Társadalomés Viselkedéstudományi Csoport (Social and Behavioral Sciences Team) felismeréseit. Különböző intézményesített formában Hollandia, Németország, Franciaország és Dánia is foglalkozik a témával. ${ }^{1}$

A viselkedésértés elméleti alapjai kapcsán először is a viselkedési közgazdaságtant (behavioural economics) kell megemlítenünk, amely a pszichológia eredményei segítségével magyarázza a gazdasági döntéshozatalt az emberi magatartásban. A viselkedési közgazdaságtan újítása abban áll, hogy a klasszikus, elsősorban racionálisan döntő ember (homo oeconomicus) szemléletmódját sok esetben pszichológiai jellemzőkkel, érzelmi motívumokkal egészíti ki.

A teljes racionalitás modelljén a viselkedési közgazdaságtan a korlátozott racionalitás elméletével is puhított, amely kimondja, hogy a gyakorlati döntések meghozatala során az egyén több korláttal is szembesül. Ilyen az alternatívákról rendelkezésre álló információk hiányos volta, az emberi agy kognitív képességeinek behatároltsága és a döntés meghozatalára rendelkezésre álló idő korlátozott menynyisége. Ezen tényezők egymással is összefüggésben állnak. ${ }^{2}$

A viselkedésértés gyakorlati alkalmazása a közgazdaságtan eredményeire építve feltárja, hogy az emberek ténylegesen miként hoznak döntéseket és hozzájárul ahhoz, hogy a kívánt hatás elérése érdekében hatékonyabb intézkedések szülessenek a társadalmi célok megvalósítására. A hagyományos, bürokratikus eljárásmódokat mellőzve a viselkedésértés újszerű megközelítéssel próbálja hatékonyabbá tenni az állami múködést.

A viselkedésértéshez kötődő egyes viselkedésbefo- lyásoló módszereknek 2008 óta gyűjtőfogalma is van. Egy ekkor megjelent könyv nyomán a nudge kifejezéssel szokás ezeket említeni. ${ }^{3}$ A nudge magyarra bökésnek, oldalba bökésnek fordítható, vagyis észrevétlen üzenetek, finom jelzések segítségével történő befolyásolásnak nevezhetjük. A fogalmat bevezető két kutató, Richard Thaler és Cass Sunstein szerint a módszer minden helyzetben alkalmazható, amikor olyan folyamatról van szó, melyben emberek viselkedését előre tervezhető módon befolyásolják, anélkül, hogy közben bármit megtiltanának nekik vagy jelentősen változtatnának az anyagi ösztönzőiken. Annak érdekében, hogy rávegyenek minket az adott döntésre, a befolyásoló (vállalat, vagy egyén) egy sor módon - anélkül, hogy annak tudatában volnánk - befolyásol. Egy új fogalommal leírva eleve megformálják a döntési helyzetet (choice architecture), és hol finoman, észrevétlenül, hol harsányan, és nem is rejtegetve meghatározott irányokba terelnek. ${ }^{4}$

A viselkedésértés azonban nem azonos a nudging technikákkal, azon túlmenően a szakpolitikai folyamatban felhasználható plusz információt jelent, amely nem garantál egyfajta, meghatározott eredményt, sőt, esetenként erre alapozva éppen hagyományos intézkedések, vagy a beavatkozás hiánya lehet javasolt. A viselkedésértés támogatói tehát nem kínálnak minden helyzetben múködő és bevethető csodaszert. Különféle helyzetek vannak, sokféle és sokszor nem racionálisan döntő és cselekvő emberekkel, ahhoz pedig, hogy e köré hatékony kormányzást építsünk, sok kísérletezésre és rugalmasságra van szükség. ${ }^{1}$

A viselkedésértés brit és amerikai gyakorlatát többen támadják, sokan egy manipulációs gépezet kiépítését és az állam túlterjeszkedését látják mindebben. A politikai jellegú kritikákon túl, egyes szakértők szerint a viselkedésértés gyakorlati eszközei csak rövidtávú, átmeneti segítséget kínálnak olyan problémákra, melyek jóval alaposabban átgondolt, strukturális megoldásokat igényelnének.

A már több mint öt éve futó brit modell eddig ezzel együtt is igazi sikertörténetnek tűnik. A viselkedésértés hatására megnőtt a szervdonorok és a hadseregbe jelentkezők száma, a britek biztonságosabb jelszavakat használnak az interneten és segített viszszaszorítani az adóelkerülést is.

\footnotetext{
' Gazdasági Együttmúködési és Fejlesztési Szervezet (Organisation for Economic Co-operation and Development - OECD)
} 
Az Egyesült Királyságban, a Miniszterelnöki Hivatalban 2010-ben pszichológusokból és magatartástudománnyal foglalkozó közgazdászokból alakult meg a BIT nevű tanácsadó csoport, eredetileg két évre szóló támogatással, amelyet a sikeres tevékenységre való tekintettel meghosszabbítottak. A BIT azóta is erős politikai támogatást élvez. Tulajdonosa 2014-től csak egyharmad részben az állam, egyharmad részben pedig a NESTA - egy innovációs jótékonysági szervezet - és egyharmad részben az alkalmazottak. Jelenleg több mint 50 szakértővel dolgoznak különböző szakterületekről, éves munkatervüket egy tudományos tanácsadó testület vizsgálja felül. Legutóbbi, 2014-2015-re vonatkozó jelentésük szerint több mint 150 vizsgálatot végeztek, több száz szemináriumot és képzést szerveztek helyi önkormányzatoknak, országos kormányszerveknek és egyéb közintézményeknek, azzal a céllal, hogy támogassák őket olyan szakpolitikák és intézkedések kialakításában, amelyek az emberek vélt magatartása helyett a tényleges viselkedést veszik figyelembe.

\section{VISELKEDÉSÉRTÉS A GYAKORLATBAN}

Az Európai Bizottság friss, 2016-os jelentése kilenc területen tekinti át a viselkedésértés jelenlegi alkalmazási módjait (piaci verseny, fogyasztóvédelem, foglalkoztatás, energiagazdálkodás, környezetvédelem, egészségügy, pénzügy, adózás, közlekedés). A jelentés dokumentumelemzés, egy felmérés eredményei, valamint 32 ország szakembereivel készített interjúk alapján készült, és helyzetképet ad a különböző szakterületeken jelenleg alkalmazott viselkedésértési beavatkozásokról, valamint a néhány országban kiépült, vagy kiépülőben lévő intézményi háttérről. Fontos megjegyezni, hogy a viselkedésértés kifejezett, szándékolt alkalmazása a bemutatott példákban csak „a jéghegy csúcsát jelenti”. Mindamellett, hogy a szakpolitikusok valóban egyre gyakrabban használják a vonatkozó tudományos kutatások eredményeit az intézkedések tervezésekor, sok beavatkozásban a viselkedési elem nem tudatosan alkalmazott. A példák ezért három kategóriába sorolhatók. Kisebb számban vannak azok a programok, amelyeket egy célzott kutatás eredményei alapján dolgoztak ki (behaviourally tested initiatives). Nagyobb számban pedig olyanok, amelyek korábbi, a viselkedésértés alkalmazására vonatkozó tapasztalatokra építenek (behaviourallyinformed initiatives), vagy amelyekben felfedezhetők viselkedésértési elemek, de nem hagyatkoznak kimondottan ilyen irányú tapasztalatokra (behaviourally-aligned initiatives).

A különböző viselkedésértési módszereket a fogyasztóvédelmi, a környezetvédelmi, az adózási és az egészségügyi intézkedésekben használják leggyakrabban, amelyek a következő ösztönzőkkel (behavioural levers) ültethetők át a gyakorlatba:
- Egyszerűsítés: leegyszerűsített információátadási/információszolgáltatási mód. Például, az adózás ösztönzésére felhasználóbarát, legördülő menüben elöre megadott válaszopciókkal ellátott online adóbevallási nyilatkozat bevezetése.

- Alapértelmezett beállítás módosítása: szerződések vagy nyilatkozatok esetén a nyilatkozat tárgyának megváltoztatása. Például, egyes országokban a szervadományozás kapcsán alapesetben mindenki potenciális donornak számít, és ezzel ellenkező szándék esetén arról kell nyilatkozni, ha az illető nem kíván donor lenni.

- A döntési környezet megváltoztatása: a választási lehetőségeket bemutató „döntési környezet" módosítása, amely lehet virtuális (honlap), vagy fizikai jellegú (az egyes áruk elhelyezése az élelmiszerboltban, az ételek feltüntetésének helye az étlapon belül). Konkrét példa, a szelektív szemétgyűjtés ösztönzése azáltal, hogy a háztartásokból gyakrabban szállítják el az újrahasznosítható hulladékot, mint a nem újrahasznosíthatót.

- „Tálalás” (framing): annak kiaknázása, hogy a kognitív torzítások miatt az emberek egy adott választási lehetőségre másként reagálnak, attól függően, hogy azt miként „tálalják”. Ennek egy negatív példája, amikor a fogyasztókat a referenciaérték megválasztásával vezetik félre, és a $20 \%$ zsírtartalmú sajt csomagolásán azt az információt tüntetik fel, hogy 80\%-ban zsírmentes.

- Társadalmi normákra való hivatkozás: pozitív változások előidézése azáltal, hogy az embereket befolyásolja, amit mások tesznek. Az adózási morál javításának egy példája, amikor az emlékeztető levélben úgy szólítják meg az adóbefizetést elmulasztó címzetteket, mint akik a kisebbségbe tartoznak az adót időben befizető több- 
séggel szemben.

- Feltűnés: szembeszökő jelek vagy információk alkalmazása, például, gyorshajtás elleni kampány során olyan üzenetek közvetítése, mint: „a halálos kimenetû autóbalesetek 48\%-ának okozója a gyorshajtás." ${ }^{1}$

A szakirodalom rengeteg információval szolgál a viselkedésértéssel kapcsolatban, amelynek áttekintésére és összegzésére született meg az Egyesült Királyságban 2010-ben az ún. MINDSPACE keretrendszer, amelyet a BIT is alkalmaz tevékenysége során. A keretrendszer áttekinthető formában mutatja be, hogy milyen jellemzők mentén vagyunk befolyásolhatók, lehetővé téve a fent említett viselkedésértési módszerek alkalmazását. ${ }^{5}$ [1. ábra]
A racionális döntés elmélete szerint döntéseink során figyelembe vesszük az összes rendelkezésre álló információt, és saját magunk számára előnyös, következetes lépéseket teszünk. A valóságban azonban döntéseinkben hosszú és rövid távú célok ütköznek össze. Például, egyszerre szeretnénk megtakarítással magas nyugdíjat elérni, ezzel egy időben azonban sokat költeni, valamint nemcsak a saját, de mások érdekeit is szem előtt tartjuk (megjelenik a kölcsönösség, valamint az altruizmus elve), túlbecsüljük a nagy horderejü, de valószínútlen események bekövetkeztét (például, lottónyeremény), és szenvedünk attól, ha túl sok információ birtokában, túl sok lehetőség közül kell választanunk (például, vásárlás során).

1. ábra: Magatartástudomány egyszerüen: A MINDSPACE jelentésben összegzett befolyásoló tényezők

\begin{tabular}{l|l}
\multicolumn{2}{|l}{ MINDSPACE } \\
\hline Messenger (az üzenet közvetítője) & $\begin{array}{l}\text { Az információt közvetítő személye nagyban befolyásol minket } \\
\text { Az ösztönzőkre adott válaszreakcióinkat előrelátható mentális torzítások } \\
\text { alakítják, mint például, a veszteség elkerülésére való törekvés }\end{array}$ \\
\hline Incentives (ösztönzők) & Erősen befolyásol bennünket, hogy mit tesznek mások \\
\hline Norms (értékek) & Az előre beállított válaszlehetőségre hagyatkozunk \\
\hline Defaults (alapértelmezés) & Figyelmünket az új, számunkra relevánsnak tűnő információkra irányítjuk \\
\hline Salience (feltünés) & Tetteinket gyakran tudattalan mozgatórugók irányítják \\
\hline Priming (előhangolás) & Érzelmi asszociációnk erősen alakítják tetteinket \\
\hline Affect (érzelmek) & $\begin{array}{l}\text { Igyekszünk a nyilvánosan tett ígéreteinknek megfelelően cselekedni, vala- } \\
\text { mint viszonzást nyújtani }\end{array}$ \\
\hline Commitment (elköteleződés) & Úgy cselekszünk, hogy jól érezzük magunkat \\
\hline Ego (én)
\end{tabular}

Forrás: Applying behavioural insight to health. Cabinet Office. Behaviour Insights Team. 2010

\section{A VISELKEDÉSÉRTÉS ALKALMAZÁSA AZ EGÉSZ- SÉGFEJLESZTÉSBEN}

Az egészségfejlesztési beavatkozások napjainkig jellemzően a meggyőződések és attitűdök megváltoztatását célozták információátadás, illetve különböző ösztönzők segítségével, vagy a tudatos döntésekre próbáltak hatni, kampányok, pénzügyi intézkedések, és hagyományos, életmódra irányuló beavatkozások révén. Ez viszont nem jelenti azt, hogy ezek az intézkedések részben ne építenének a magatartástudomány eredményeire. ${ }^{7}$

Jól tükrözik ezt a már említett bizottsági jelentésben ismertetett, az egészséges táplálkozásra és dohány- 
zás visszaszorítására irányuló, alábbi egészségfejlesztési példák is, amelyek viselkedésértési elemeket tartalmaznak, de nem előzte meg őket célzott vizsgálat, vagy más gyakorlatok tapasztalatainak tanulmányozása (behaviourally-aligned initiatives).

Lettországban a Betegségmegelőzési Központ (Disease Prevention and Control Centre) és az Egészségügyi Minisztérium 2014-2015 folyamán figyelemfelhívó kampányt folytatott a dohányzás visszaszorítására a fiatalkorúak körében, Free („Szabadulj meg") címmel. A kampány keretében olyan applikációt fejlesztettek, amely a dohányzás csökkentése révén keletkező (napi, havi és éves) megtakarítást kiszámolja és a fiatalok számára vonzó javak képében meg is jeleníti. Például, egy laptop képéhez a következő üzenet társul: „ez csak egyike azoknak a dolgoknak, amit a cigarettára szánt pénzből vehetnél". A kampány tehát olyan viselkedésbeli mozgatórugókra épít, mint az információ tálalásának módja, a fiatalok számára figyelemfelhívó képek és üzenetek, és az azonnali jutalomban való részesülés ígérete. Portugáliában az Egészségügyi Minisztérium a passzív dohányzás veszélyeire hívta fel a figyelmet televíziós és rádiós megjelenésekkel, poszterekkel, amelyek az információ tálalási módját és az érzelmekre való hatást alkalmazták eszközként. Például, az egyik rövidfilm 30 másodperben egy alvó csecsemőt mutat, a következő hangalámondással: „A dohányfüst $80 \%$-a láthatatlan, és ha egyvalaki dohányzik, akkor mindenki dohányzik". Ezt követően a baba füstöt lélegez ki a száján. Lettországban a terhesség alatti dohányzás megelőzésére hasonló kampányanyag készült, amelyben egy magzat jelenik meg cigarettával a szájában a következő üzenettel:„,Ha dohányzol, a gyermeked is dohányzik”.

Az egészséges táplálkozás elősegítése terén olyan gyakorlatokkal találkozhatunk, mint például az a horvátországi projekt, amelynek keretében a 2015/2016-os tanévben 884 általános iskolában ingyen kínálták a zöldséget és a gyümölcsöt az iskolai ebédekhez (nudging). Észtországban a kormány online információt szolgáltat az egészséges táplálkozásról a lakosság számára, egyszerűen értelmezhető és használható formában. A napi étkezés optimális sótartalmát többek közt vizuális elemek segítségével lehet kiszámolni, úgy, hogy egy virtuális tányérba pakolhatják a felhasználók az ételeket. A program a megengedett sómennyiség felső határának elérésekor látványosan jelez és tippeket is ad a sómennyi- ség csökkentésére. Ez a gyakorlat az egyszerűsítésre, a szembeszökő vizuális elemekre és a személyre szabott információk vonzerejére épít. Izlandon pedig egy zöld kulcslyuk ikonnal jelölik a kis zsírsó-, és cukortartalmú élelmiszereket, amellyel feltûnő és egyszerû módon segítik a vásárlót az egészséges termékek megtalálásában. ${ }^{1}$

Szintén izlandi, a BIT által kiadott szakmai anyagban idézett példa a Lazy Town („Lusta város”) ${ }^{8}$ nevü, az egészséges életmód elősegítésére irányuló televíziós gyermekműsor, amely világszerte ismert, és amelynek 1996-os indulása óta csökkent az elhízott gyermekek száma Izlandon. Az egészséges életmódot a Sportacus nevú szuperhős népszerűsíti a gyermekek körében, és számos kezdeményezés született a müsor jegyében a kormánnyal és a magánszektorral együttmúködésben. Például, a 4-7 éves gyerekeknek egy ún. energia megállapodást (Energy Contract) küldtek, amelyet szüleikkel együtt aláírhattak, és amelynek keretében jutalmat érdemeltek az egészséges étkezésért, az aktív időtöltésért vagy a korai lefekvésért. Egy szupermarket láncolat a Lazy Town által adott névvel, a "sportcukorka” (Sports Candy) jelzővel látta el a gyümölcsöket és zöldségeket, amely 22\%-os növekedést eredményezett az eladási arányban. ${ }^{5}$

Az előző példa rávilágít a különböző (helyi) partnerek szerepére a viselkedésértés alkalmazásában. A Helyi Önkormányzatok Szövetsége az Egyesült Királyságban esettanulmányokat jelentetett meg 2016-ban a viselkedésértés és az egészség témakörében, amelyben a következő 10 tanácsot fogalmazta meg az önkormányzatok számára a viselkedésértés elméletének gyakorlatba való átültetéséhez:

- Egy témafelelős kijelölése, és a munkatársak bátorítása, hogy felvállalják a témafelelős szerepét.

- Kormányzati szakemberekkel való kapcsolatfelvétel a viselkedésértés témájában - az Egyesült Királyság Egészségügyi Minisztériumának népegészségügyi szerve (Public Health England) által múködtetett, a tapasztalatcserét elősegítő szakértői hálózatba való bekapcsolódás.

- Helyi szakértelem bevonása, pl. egyetemeken vagy a nonprofit szektoron keresztül.

- A munkatársak képzése a viselkedésértési technikák terén, kiemelten a lakossági be- 
avatkozások vonatkozásában.

- A változtatni kívánt viselkedés pontos meghatározása, a célcsoport és a viselkedési környezet elemzésére alapuló beavatkozások tervezése.

- A változtatni kívánt magatartás tanulmányozásához elméleti keretrendszer, pl. a COM-B modellii felhasználása, központban a viselkedésváltoztatás kerekével.

- Egy beavatkozás tervezésekor minden lehetséges opció átgondolása, a meglévő rendszerek és szolgáltatások fejlesztésétôl az új intézkedésekig.

- Annak biztosítása, hogy a viselkedésváltoztatásra irányuló beavatkozások a változás fenntartását is célozzák és ne egyszeri eredményt hozzanak.

- Idő és forrás megteremtése a viselkedésváltoztatásra irányuló beavatkozások megfelelő, rövid-, közép-, és hosszú távú eredményeinek értékelésére.

- Amennyiben lehetséges, a meglévő rendszereken belül rendelkezésre álló adatforrások felhasználása a kivitelezhetőség és fenntarthatóság érdekében, mivel a viselkedésváltoztatási projektek általában alacsony intenzitású beavatkozások.

Egy, a helyi önkormányzatok által jól kiaknázható lehetőség, amikor az egyes élethelyzetek változásakor nyújtanak támogatást az egészségesebb életmód kialakításában a lakosság számára. Kutatási eredmények szerint az emberek jóval nagyobb valószínúséggel változtatnak valamin, amikor megszokott rutinjukat egy új élethelyzet - például költözés, gyermekszületés, iskolakezdés - megszakítja. Az önkormányzatok ilyen esetekben gyakoribb kapcsolatba kerülnek a lakossággal, ezért London Borough of Hanslow városrészén az önkormányzat erre alapozva indította el az Európai Bizottság által támogatott SWITCH („VÁLTS”) projektet, az aktív közlekedés elősegítésére. A kampány az iskolakezdés előtt álló gyermekek családjait célozta meg. A 2015-ös iskolaév kezdetén az önkormányzat kapcsolatba lépett a szülőkkel, és személyre szabott utazási taná- csokkal, térképekkel látta el őket, amely abban segített, hogy biztonságos és népszerü, gyaloglásra alkalmas útvonalakat mutassanak az iskolába vezető út egy részére vagy egészére. Ezután iskolák közötti verseny indult a már létező, Beat the Streets („Győzd le az utcát”) projektre építve. A verseny során a gyerekek kártyaleolvasók segítségével gyüjthettek pontokat egy kártyára, a legyalogolt távolságok után. 21 iskolából több mint 11300 gyermek vett részt a hat hétig tartó projektben. A versenyt megnyerő iskola igazgatója szerint a projekt óriási hatással volt a közösségre és növelte az iskolába gyalog vagy kerékpárral érkező gyerekek számát. A városrész következő hasonló terve a gyermekek első születésnapjára küldött képeslap, melyben arra buzdítják a szülőket, hogy vigyék el gyermeküket fogorvoshoz. ${ }^{9}$

A viselkedésértés - közvetve vagy közvetlenül szakpolitikai szinten is megjelenik olyan egészségfejlesztési dokumentumokban, mint az Egészségügyi Világszervezet (WHO) Globális táplálkozási, fizikai aktivitási és egészségstratégiája ${ }^{10}$, az ENSZ közgyűlésen 2011-ben elfogadott Nem-fertőző megbetegedésekkel kapcsolatos politikai deklaráción ${ }^{11}$, vagy a WHO 2013-as Cselekvési terve a nem-fertőző megbetegedések megelőzésére. ${ }^{12} \mathrm{~A}$ WHO ezekben a dokumentumokban elismeri mind a társadalmi, mind a fizikai környezet szerepét a viselkedésváltozásban, és nem zárja ki a viselkedésértés alkalmazását, konkrét ajánlásokkal azonban nem szolgál arról, hogy ezeket miként lehet átültetni a gyakorlatban az egészségfejlesztésbe. ${ }^{7}$

\section{ÖSSZEFOGLALÁS}

A magatartástudomány eredményei új utakat kínálnak az emberi döntéshozatal folyamatának megértésében, innovatív megoldásokkal segítve a viselkedésváltozást, és az egészségesebb életmódot, a hagyományos intézkedések (pl. törvények, szabályozások, pénzügyi ösztönzők) kiegészítéseként. A viselkedésértés alkalmazása hatékonyabbá teheti az intézkedéseket, azonban számos kérdést is felvet a legitimáció, a hatásosság és a tudományos megala-

iSusan Michie és társai által kidolgozott viselkedésváltoztatási keretrendszer. A COM-B modell szerint a képességek (Capability), a körülmények (Opportunity), és a motiváció (Motivation) együttesen befolyásolják a viselkedést (Behaviour) úgy, hogy az egyrészt visszahat a befolyásoló tényezőkre, másrészt a befolyásoló tényezők egymásra is hatnak. 
pozottság tekintetében. Míg a paternalista megközelítéssel szemben a szabad választás jogát nem sértve tereli a döntéseket, ennek legitimációja azonban annak függvénye is, hogy a közösség elfogadja-e a tervezők által megalkotott döntési környezetet. A kritika része az is, hogy mennyire lehet tartós a viselkedésértési intézkedés hatása, amennyiben nem tanuláson és személyes, tudatos döntésen alapul. Jelenleg arra vonatkozóan sem állnak rendelkezésre kutatási eredmények, hogy a viselkedésér- tés által leírt döntési mechanizmusok miként múködnek különböző csoportok körében, a kulturális és társadalmi környezettől függően. Továbbá, kevés viselkedésértési beavatkozás hatását értékelték lakossági szintű és tartós viselkedésváltozás tekintetében, amely hosszú távon egészségnyereséghez vezethetne. ${ }^{7}$ A viselkedésértés átlátható és következetes alkalmazása érdekében a jövőben javasolt tehát a beavatkozások hatásosságának vizsgálata, és az ezzel kapcsolatos tapasztalatcsere.

\footnotetext{
${ }^{1}$ Joana Sousa Lourenço, Emanuele Ciriolo, Sara Rafael Almeida, and Xavier Troussard: Behavioural insights applied to policy: European Report 2016. EUR 27726 EN; doi:10.2760/903938 https://ec.europa.eu/jrc/en/publication/eurscientific-and-technical-research-reports/behavioural-insights-applied-policy-european-report-2016 (Elérve: 2016.07.05.)

${ }^{2}$ Golovics József: Korlátozott racionalitás és altruizmus: behaviorizmus a közgazdaság-tudományban, Hitelintézeti Szemle, 14. évf. 2. szám, 2015. június, 158-172. o.

${ }^{3}$ Richard H. Thaler, Cass R. Sunstein: Nudge - Jobb döntések egészségről, pénzről és boldogságról - a pénzügyi válság után. Manager Könyvkiadó Kft. 2011

${ }^{4}$ Marosán György: A gazdasági döntés evolúciós elméletének néhány kérdése a döntési helyzet meta- és utóértékelése, mint a döntés alapeleme, Köz-Gazdaság 2011/1.

${ }^{5}$ Applying behavioural insight to health. Cabinet Office. Behaviour Insights Team. 2010 https://www.gov.uk/government/uploads/system/uploads/attachment data/file/60524/403936 Behaviourallnsight acc.pdf (Elérve: 2016.07.06.) ${ }_{7}^{7}$ Alemanno, Alberto, A Behavioural Approach to Health Promotion: Informing the Global NCD Agenda with Behavioural Insights (August 4, 2014). in A. Alemanno - A. Garde, Regulating Lifestyle - Europe, Alcohol, Tobacco and Unhealthy Diets, Cambridge University Press (2014 Forthcoming); HEC Paris Research Paper No. LAW-2014-1054. Available at SSRN: http://ssrn.com/abstract=2475805 or http://dx.doi.org/10.2139/ssrn.2475805 (Elérve: 2016.06.20.) ${ }^{8}$ http://www.lazytown.com/ (Elérve: 2016.07.06.)

${ }_{9}^{9}$ Behavioural insights and health. Case Studies. Local Government Association. January 2016. http://www.local.gov.uk/documents/10180/7632544/L16-11+Behavioural+insights/Of9b83a6-cab1-43c2-ba99-2f381c1d2630 (Elérve: 2016.06.19.)

${ }^{10}$ World Health Organisation. Global Strategy on Diet, Physical Activity and Health. http://www.who.int/dietphysicalactivity/en/ (Elérve: 2016.07.05.)

${ }^{11}$ Political Declaration of the High-level Meeting of the General Assembly on the Prevention and Control of Noncommunicable Diseases. 24 January 2012.

http://www.who.int/nmh/events/un ncd summit2011/political declaration en.pdf (Elérve: 2016.07.05.)

12 Global Action Plan for the Prevention and Control of Noncommunicable Diseases. World Health Organisation. 2013. http://www.who.int/nmh/events/2013/revised draft ncd action plan.pdf (Elérve: 2016.07.05.)
} 